\title{
Mycorrhiza Reduces Phosphorus Uptake from Struvite in Rye (Secale cereale L.) Plants
}

\author{
Sanja Annabell Schwalb ${ }^{1}$ (i) $\cdot$ Michael Hemkemeyer $^{1}$ (D) Conor Watson $^{1}$ (i) $\cdot$ Florian Wichern $^{1}$ (D)
}

Received: 24 April 2021 / Accepted: 11 September 2021 / Published online: 5 October 2021

(c) The Author(s) 2021

\begin{abstract}
To reduce dependency on inorganic phosphorus (P) fertiliser, secondary P fertilisers such as struvite are becoming more important. However, the $\mathrm{P}$ uptake of these new fertilisers by plants is often not known and may be enhanced by plant associated microorganisms. We therefore investigated the effect of arbuscular mycorrhizae (AM) on P uptake in rye (Secale cereale L.), grown in the middle compartment of a box with chambers separated by a $30 \mu \mathrm{m}$ mesh allowing fungal hyphae but not roots to penetrate. Plants with (AM) or without (control) mycorrhizae (Rhizophagus irregularis) were grown in a P limited sand medium for 72 days. After harvest, plants were analysed for mycorrhizal colonization, shoot and root development and nutrient $(\mathrm{P}, \mathrm{Ca}, \mathrm{Mg}$ ) uptake. Further, $\mathrm{pH}$ was measured in each compartment. Shoot biomass of both treatments was not different, but root biomass was significantly lower in AM plants. Despite plants of the AM treatment being colonised by mycorrhizae, their P uptake was substantially lower compared to the control treatment, but root nutrient concentration was higher. Even though the $\mathrm{pH}$ in the mycorrhizal compartment of the AM treatment was significantly lower compared to the control, water- and CAL-extractable $\mathrm{P}$ were similar, indicating little $\mathrm{P}$ uptake from this compartment. Extractable $\mathrm{P}$ was reduced only in the root compartment of the control, which was associated with a lower $\mathrm{pH}$ compared to the AM treatment. In conclusion, mycorrhizae did not increase P uptake from struvite in rye plants. Non-mycorrhizal plants which invested more biomass into roots took up more P.
\end{abstract}

Keywords AMF $\cdot$ Biomass partitioning $\cdot$ Rhizobox $\cdot$ Stem

\section{Introduction}

The worlds' phosphorus $(\mathrm{P})$ reserves are limited, and a more sustainable use of the resource is essential to ensure the future availability of P-fertilisers (Schoumans et al. 2015; Tarayre et al. 2016). The use of alternatives like recovering $\mathrm{P}$ from waste can contribute to a more sustainable P-fertiliser use (van der Wiel et al. 2020). Phosphorus fertilisers can be recovered in the form of struvite $\left(\mathrm{MgNH}_{4} \mathrm{PO}_{4} \cdot 6 \mathrm{H}_{2} \mathrm{O}\right)$ from sewage sludge (Tarayre et al. 2016), animal waste (Schoumans et al. 2015) or dairy processing effluent (Uysal and Kuru 2013; Watson et al. 2019). Even though water soluble $\mathrm{P}$ in struvite is often low, struvite or similar secondary minerals can be as effective as commercial P fertilizer (Muys

Florian Wichern

florian.wichern@hsrw.eu

1 Department of Soil Science and Plant Nutrition, Faculty of Life Sciences, Rhine-Waal University of Applied Sciences, Marie-Curie Str. 1, 47533 Kleve, Germany et al. 2021; Watson et al. 2019) at the same time adding other valuable plant nutrients, such as nitrogen, magnesium or potassium (Watson et al. 2019, 2020).

The plant-fungal symbiosis between most plant species and arbuscular mycorrhizal fungi (AM) can also contribute to a more efficient use of novel $\mathrm{P}$ resources. It is well known that AM contribute to the $\mathrm{P}$ uptake in plants by their capability to explore additional soil volume for P (Brundrett and Abbott 2004; Hayman and Mosse 1972). Phosphorus has limited diffusion capacities in the soil, and P-depletion zones can form around the root (Smith and Read 2008b). AM can acquire $\mathrm{P}$ which would otherwise be out of reach for the root, for example, by extending the hyphal network beyond that of the root or by reaching into smaller soil pores due to the smaller diameter of hyphae compared to roots (Smith and Read 2008a). However, high P availability reduces root colonisation by mycorrhizae and symbiotic $\mathrm{P}$ uptake (Nouri et al. 2014). Making use of secondary $P$ fertilisers together with beneficial microorganisms, such as mycorrhizae, for more efficient exploration of soil $\mathrm{P}$ resources can contribute to a 
reduced reliance on conventional $\mathrm{P}$ fertilisers and thereby improve the sustainable usage of $\mathrm{P}$ in agriculture.

The ability of AM to supply P to the plant by utilising struvite as a $\mathrm{P}$ source in the soil has not yet been researched. It is unclear if the low level of water soluble $P$ in struvite would allow mycorrhization of roots. Rye plants were used in this study, as they are an important cereal crop, used for food, feed and bioenergy production and can be grown on poor soils of light texture where it is comparably more productive than other cereals (Wrigley and Bushuk 2017). The ability of the AM species used in this experiment to access the $\mathrm{P}$ supplied in the struvite in an otherwise $\mathrm{P}$ limited environment was tested by comparing the plant shoot $\mathrm{P}$ contents between the AM-inoculated plants and the non-inoculated ones. As the experiment took place in boxes with compartments differing in accessibility for roots and hyphae, the remaining $\mathrm{P}$ contents within these different compartments were furthermore compared. It was hypothesised that plant $P$ contents of the AM-inoculated plants would be higher compared to the non-inoculated plants and that $\mathrm{P}$ removal from AM-influenced compartments would be greater compared to the control compartments.

\section{Materials and Methods}

\subsection{Experimental Setup}

The experiment was based on the design for 'rhizoboxes' by $\mathrm{Li}$ et al. (1991). Ten stainless steel boxes were made containing five compartments each (Fig. 1). The central or root compartment $(16 \times 4.5 \times 16 \mathrm{~cm})$ which allowed for plant root and fungal hyphal growth was separated by a $30 \mu \mathrm{m}$ mesh from two adjacent compartments on either side of the root compartment. These compartments (referred to as the mycorrhizal compartments; $16 \times 4.5 \times 16 \mathrm{~cm}$ ) allowed for hyphal growth only, due to the mesh which is impenetrable to plant roots but not to fungal hyphae. Adjacent to each mycorrhizal compartment was the bulk soil compartment $(16 \times 10 \times 16 \mathrm{~cm})$. A $0.45 \mu \mathrm{m}$ mesh, which excluded fungal hyphae, separated the bulk soil compartment from the mycorrhizal compartment. The bulk soil compartment allowed for the assessment of extractable struvite without direct root or hyphal influence, but at the same time can indicate if roots or hyphae potentially influence $\mathrm{P}$ extractability or $\mathrm{P}$ removal in their neighbouring compartments as demonstrated by Li et al. (1991). All chambers were filled with quartz sand $(\mathrm{pH}=6.31,0.1-0.5 \mathrm{~mm})$ that had been sterilised by autoclaving. The root and mycorrhizal compartments were filled with $1.6 \mathrm{~kg}$ of sand each and the bulk soil compartments with $3.2 \mathrm{~kg}$ of sand each. Each

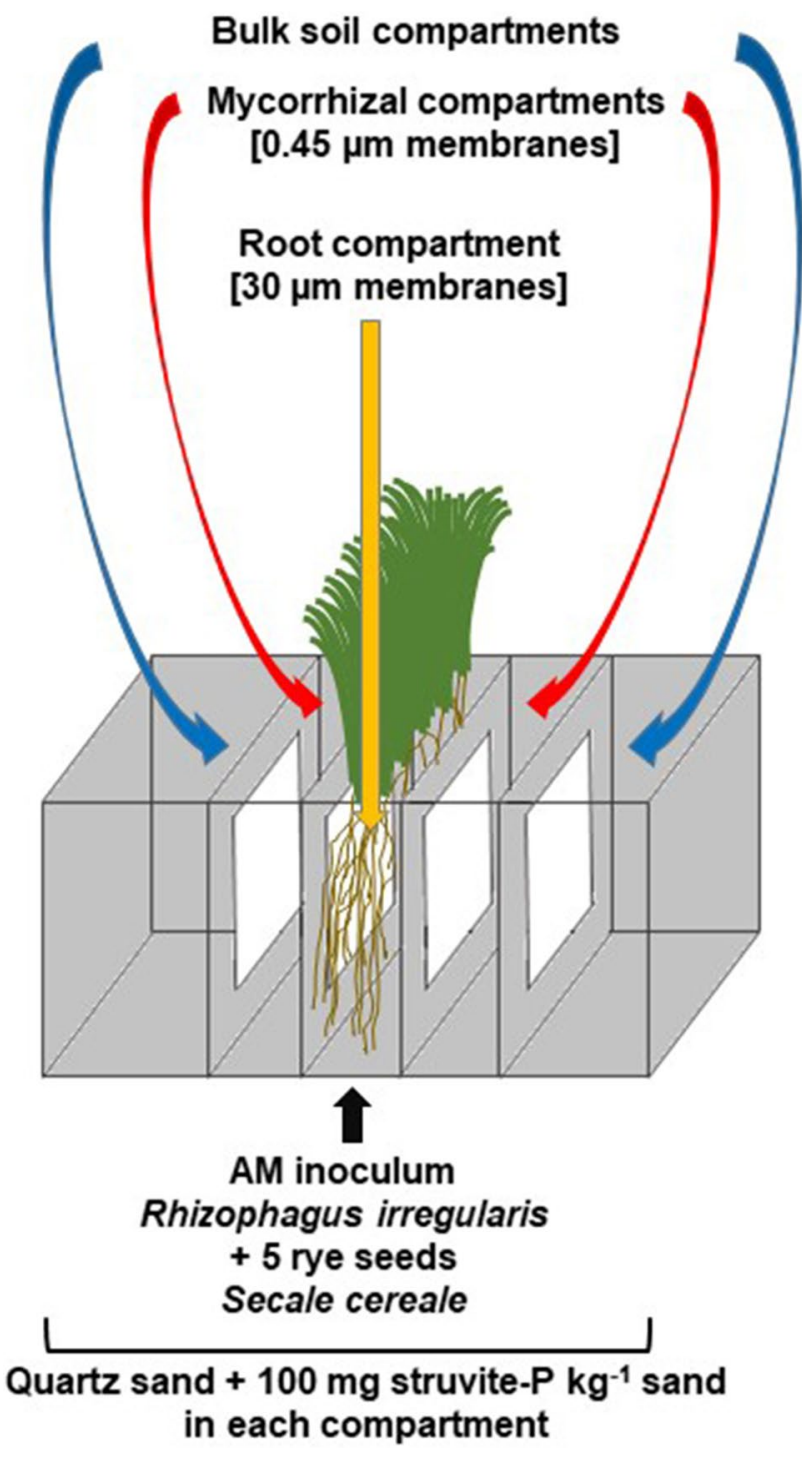

Fig. 1 Illustration of the experimental box with different compartments (roots, mycorrhiza, bulk soil). Root and mycorrhizal compartments were separated by a $30 \mu \mathrm{m}$ mesh and mycorrhizal and bulk soil compartments by a $0.45 \mu \mathrm{m}$ mesh

compartment received the equivalent of $100 \mathrm{mg} \mathrm{P} \mathrm{kg}^{-1}$ sand in the form of struvite, which was $160 \mathrm{mg} \mathrm{P}$ and $320 \mathrm{mg} \mathrm{P}$ for each root/mycorrhizal compartment and each bulk soil compartment, respectively. The struvite was derived from dairy plant effluent by precipitation (Watson et al. 2019). The crystalline struvite was evenly mixed in throughout the sand. A layer of the commercial AM inoculum, i.e. Rhizophagus irregularis (Błaszk., Wubet, Renker \& Buscot) C. Walker \& A. Schüßler, -colonised root material in a sand substrate (Sprint, INOQ GmbH, Schnega, Germany) was added about $2 \mathrm{~cm}$ below the surface of each root compartment in half (five) of the boxes. As advised by the producer, 
$20 \mathrm{~mL}$ of the inoculum per plant was added to the sand resulting in 2,900 mycorrhizal units per box. Five rye seeds (Secale cereale L. var. Bono, KWS SAAT SE, Einbeck, Germany) were planted in each root compartment. The seeds had been surface-sterilised in $10 \%$ hydrogen peroxide for $10 \mathrm{~min}$, before rinsing with distilled water and soaking in a moist tissue overnight prior to planting. The method for irrigation was similar to that of Li et al (1991). Briefly, jute wicks were buried in each compartment and connected to the water and nutrient supply bottles. As the boxes contained only sand and struvite, further essential nutrients, except for $\mathrm{P}$, were supplied as a half strength modified Hoagland solution via the wick system as is common for pot experiments. The final concentrations ( $\mathrm{mg} \mathrm{kg}^{-1}$ sand) of nutrients supplied were $\mathrm{KNO}_{3} 33.5, \mathrm{Ca}\left(\mathrm{NO}_{3}\right)_{2} \cdot 4 \mathrm{H}_{2} \mathrm{O} 62.7, \mathrm{NH}_{4} \mathrm{NO}_{3}$ 10.6, $\mathrm{MgSO}_{4} \cdot 7 \mathrm{H}_{2} \mathrm{O} 32.7, \mathrm{Fe}$-EDTA $2.4, \mathrm{MnSO}_{4} \cdot \mathrm{H}_{2} \mathrm{O}$ $0.16, \mathrm{H}_{3} \mathrm{BO}_{3} 0.04, \mathrm{CuSO}_{4} \cdot 5 \mathrm{H}_{2} \mathrm{O} 0.16, \mathrm{ZnSO}_{4} \cdot 7 \mathrm{H}_{2} \mathrm{O} 0.16$, $\left(\mathrm{NH}_{4}\right)_{6} \mathrm{Mo}_{7} \mathrm{O}_{24} \cdot 4 \mathrm{H}_{2} \mathrm{O} 0.39$ and $\mathrm{Co}\left(\mathrm{NO}_{3}\right)_{2} \cdot 6 \mathrm{H}_{2} \mathrm{O} 0.04$. After one month, the addition of nutrients was discontinued, and the plants were watered with distilled water only, to avoid over-fertilisation. The rhizoboxes were placed in a greenhouse chamber under controlled temperature (set to $22^{\circ} \mathrm{C}$, but reaching an average of $26^{\circ} \mathrm{C}$ during the day and $22^{\circ} \mathrm{C}$ at night) and light ( $16 \mathrm{~h}$ light period; approximately $105 \mu \mathrm{mol}$ PAR $\mathrm{m}^{-2} \mathrm{~s}^{-2}$ at pot level)) conditions. All five seeds had successfully germinated in the pots. After 26 days, one plant from each box was carefully removed and checked as proxy for mycorrhizal colonisation of the roots within the entire compartment. The remaining four plants from each box were grown for 72 days before harvesting them at the vegetative growth stage (BBCH 23-29) (Meier 2018). The difference in plant $\mathrm{P}$ between the inoculated boxes and the control (without AM inoculum) boxes was defined as the contribution of struvite-derived $\mathrm{P}$ to the plant by the AM.

\subsection{Mycorrhizal Colonisation of Roots}

The harvested roots were washed and cut into approximately $1 \mathrm{~cm}$ pieces and suspended in water. For staining, two $0.5 \mathrm{~g}$ sub-samples were taken from all replicates. The root sub-samples were submersed in $10 \%$ potassium hydroxide $(\mathrm{KOH})$ solution for de-pigmentation and removal of cell contents (clearing-step) from the root material. After 6 days in the $\mathrm{KOH}$ solution, the roots were taken out and rinsed carefully with water before submersion in a $0.1 \mathrm{M}$ hydrochloric acid $(\mathrm{HCl})$ solution for $30 \mathrm{~min}$. Subsequently, the staining of the roots in a $0.05 \%$ solution of trypan blue in lactoglycerol (concentrated lactic acid:glycerol:distilled water ratio of 1:1:1.34; $\mathrm{v} / \mathrm{v} / \mathrm{v}$ ) solution was done overnight at room temperature. Before observation under the microscope, the roots were de-stained in lactoglycerol solution for a few minutes to remove the excess stain.

\subsection{Analyses}

At harvest, root and shoot material was dried at $70{ }^{\circ} \mathrm{C}$ for three days to obtain the dry matter content, subsequently ground in a centrifugal and a ball mill and analysed for $\mathrm{C}$ and $\mathrm{N}$ (Elemental analyser NA1500, Thermo Scientific, Waltham, MA, USA). About $0.5 \mathrm{~g}$ of the finely ground shoot or root material was used to determine the $\mathrm{P}$, calcium $(\mathrm{Ca})$ and magnesium $(\mathrm{Mg})$ concentrations (via an Optima 8000 ICP-OES, Perkin Elmer, Baesweiler, Germany) after concentrated sulphuric acid/ hydrogen peroxide digestion.

At the end of the experiment, the $\mathrm{pH}$ of the sand was measured in $0.01 \mathrm{M} \mathrm{CaCl}_{2}(1: 2.5 \mathrm{w} / \mathrm{v})$. Plant-available $\mathrm{P}$ was extracted from air-dried sand with distilled water and also with calcium-acetate-lactate $(\mathrm{CAL})$ solution $(0.1 \mathrm{M} \mathrm{Ca}-$ lactate $+0.1 \mathrm{M} \mathrm{Ca}$-acetate $+0.3 \mathrm{M}$ acetic acid) according to Schüller (1969) at a substrate to solution ratio of 1:20. The CAL method represents acid soluble $P$ fractions accessible by plants as compared to only water available P. It was expected that struvite-P is mostly acid soluble. The $\mathrm{P}$ in the water and CAL extracts was measured spectrophotometrically (GENESYS ${ }^{\mathrm{TM}}$ 10S UV-Vis Spectrophotometer, Thermo Fischer Scientific, Waltham, USA) with the vanadate-molybdate method (Murphy and Riley 1962) at $436 \mathrm{~nm}$ wavelength.

\subsection{Calculations and Statistical Analyses}

Data for both mycorrhizal compartments and also for both bulk soil compartments per box were pooled for statistical analyses and not considered separately. All statistical analyses were performed using $\mathrm{R}$ (R Core Team 2017). The biomass, shoot and root $\mathrm{C}, \mathrm{N}, \mathrm{P}, \mathrm{Mg}$ and $\mathrm{Ca}$ data were analysed for statistically significant differences with a two-tailed unpaired $t$-test in the case of normal distribution, as assessed via quantile-quantile plots. In the case of a non-normal distribution the Wilcoxon rank-sum test was chosen. The $\mathrm{pH}$ and plant-available $\mathrm{P}$ data was analysed with a mixed effects model using the R-package nlme (Pinheiro et al. 2017). The model contained the two fixed effects 'Treatment' and 'Compartment' and the random effect 'Box'. The model was tested for significant effects of treatment, compartment and the interaction between treatment and compartment using the anova command in $\mathrm{R}$. If the interaction term between treatment and compartment was not statistically significant, model simplification was performed by removing the interaction term in a subsequent model. Post hoc testing was performed by calculating estimated marginal means with the R-package emmeans (Lenth 2019) and supported by the cld-command of the package multcompView (Graves et al. 2015). Correlation coefficients were based on Pearson. 


\section{Results}

\subsection{Mycorrhizal Colonisation of Roots}

After 72 days, roots of all four plants in the inoculated boxes were colonised, although the colonisation of the plant roots was not quantified. Spores and hyphae (Supplementary material Fig. S1) entering the root cortex cells were visible, but no arbuscules could be identified. However, plant responses clearly indicated an effect of AM on plants as described below.

\subsection{Biomass Dry Matter and C, N, P, Mg and Ca Content}

At harvest, morphological differences of the roots were observed between the control and the AM treated plants. Control plants had developed a very extensive root system dominated by fine roots which was engulfing the whole compartment. A 'carpet' of very fine roots grew tightly against the membranes on each side of the root compartment. The AM plant roots, on the contrary, had developed thicker roots and fewer fine roots. The 'carpet' layer was absent or very weakly developed. The average shoot biomass of control and AM plants did not differ significantly (Table 1). In contrast, the root biomass of control plants was significantly higher compared to the AM plants (Table 2). AM plants had significantly higher $\mathrm{C}$ and $\mathrm{N}$ shoot and root concentrations, but total shoot $\mathrm{C}$ and total shoot and root $\mathrm{N}$ did not differ significantly between treatments (Tables 1 and 2).

No P deficiency symptoms were visible on any of the plants at harvest. The above-ground biomass of the control plants had a significantly higher total $\mathrm{P}$ content compared to the AM plants (Table 1). This was caused by the significantly higher $\mathrm{P}$ concentration in the shoots of the control plants. For the root $\mathrm{P}$ concentration $\left(\mathrm{mg} \mathrm{kg}^{-1}\right)$, this was reversed. But due to their higher biomass, the average total $\mathrm{P}$ uptake $\left(\mathrm{mg} \mathrm{pot}^{-1}\right)$ of the roots was 6.3 and 3.5 for control and AM plants respectively and was therefore also significantly higher for control plants. In addition to a higher $\mathrm{P}$ uptake, control plants also took up more $\mathrm{Ca}$ and $\mathrm{Mg}$ (Table 2). However, differences in the allocation of nutrients between shoots and roots can be seen between treatments when comparing molar $\mathrm{C}: \mathrm{N}, \mathrm{N}: \mathrm{P}, \mathrm{Mg}: \mathrm{Ca}, \mathrm{P}: \mathrm{Ca}$ and $\mathrm{P}: \mathrm{Mg}$ ratios (Tables 1 and 2). Shoot $\mathrm{C}: \mathrm{N}$ ratios did not differ significantly, but the root $\mathrm{C}: \mathrm{N}$ ratio of $\mathrm{AM}$ plants was significantly lower. Shoot and root N:P ratios were significantly lower for control plants, suggesting a greater relative $\mathrm{N}$-limitation for control plants compared to AM plants, which is also reflected in the root $\mathrm{C}: \mathrm{N}$ ratios. The
Table 1 Above-ground biomass data and carbon, nitrogen, phosphorus, calcium and magnesium contents of shoot biomass, as well as the respective elemental ratios $(n=5)$. Elemental ratios are molar ratios. Mean \pm SD. Data analysed via two-tailed unpaired $t$-test and Wilcoxon rank-sum test, respectively. Statistically significant values are shown in bold

\begin{tabular}{|c|c|c|c|}
\hline & Control & $\mathrm{AM}$ & $t$-Value \\
\hline $\begin{array}{l}\text { Shoot dry matter } \\
{\left[\mathrm{g} \mathrm{pot}^{-1}\right]}\end{array}$ & $6.5 \pm 1.1$ & $5.5 \pm 0.8$ & 1.6426 \\
\hline $\begin{array}{l}\text { Total shoot C } \\
{\left[\mathrm{g} \mathrm{pot}^{-1}\right]}\end{array}$ & $2.5 \pm 0.4$ & $2.2 \pm 0.3$ & 2.0358 \\
\hline $\begin{array}{l}\text { Shoot C } \\
{\left[\mathrm{g} \mathrm{kg}^{-1}\right]}\end{array}$ & $383 \pm 6.3$ & $395 \pm 9.0$ & $-3.6804 * *$ \\
\hline $\begin{array}{l}\text { Total shoot } \mathrm{N}^{\mathrm{a}} \\
{\left[\mathrm{g} \mathrm{pot}^{-1}\right]}\end{array}$ & $0.092 \pm 0.004$ & $0.089 \pm 0.014$ & 51.5 \\
\hline $\begin{array}{l}\text { Shoot N } \\
{\left[\mathrm{g} \mathrm{kg}^{-1}\right]}\end{array}$ & $14.4 \pm 1.9$ & $16.2 \pm 1.4$ & $-2.3737 *$ \\
\hline C-to-N ratio & $31.5 \pm 4.2$ & $28.7 \pm 2.1$ & 1.351 \\
\hline $\begin{array}{l}\text { Total shoot P } \\
{\left[\mathrm{mg} \mathrm{pot}^{-1}\right]}\end{array}$ & $50.5 \pm 10.2$ & $25.1 \pm 4.9$ & $5.0153 * *$ \\
\hline $\begin{array}{l}\text { Shoot P } \\
{\left[\mathrm{mg} \mathrm{kg}^{-1}\right]}\end{array}$ & $7,769 \pm 1,176$ & $4,533 \pm 387$ & $5.8469 * *$ \\
\hline $\mathrm{N}$-to-P ratio & $4.2 \pm 0.9$ & $7.9 \pm 0.4$ & $-8.6737 * * *$ \\
\hline $\begin{array}{l}\text { Total shoot Ca } \\
{\left[\mathrm{mg} \mathrm{pot}^{-1}\right]}\end{array}$ & $31.1 \pm 12.8$ & $13.8 \pm 11.8$ & 2.2199 \\
\hline $\begin{array}{l}\text { Shoot Ca } \\
{\left[\mathrm{mg} \mathrm{kg}^{-1}\right]}\end{array}$ & $4,999 \pm 2,675$ & $2,326 \pm 1,667$ & 1.8955 \\
\hline $\begin{array}{l}\text { Total shoot Mg } \\
{\left[\mathrm{mg} \mathrm{pot}^{-1}\right]}\end{array}$ & $45.1 \pm 14.1$ & $33.3 \pm 10.5$ & 1.5042 \\
\hline $\begin{array}{l}\text { Shoot Mg } \\
{\left[\mathrm{mg} \mathrm{kg}^{-1}\right]}\end{array}$ & $6,820 \pm 1,035$ & $5,945 \pm 1,329$ & 1.1625 \\
\hline Mg-to-Ca ratio & $2.8 \pm 1.3$ & $5.6 \pm 2.7$ & -2.0962 \\
\hline P-to-Ca ratio & $2.7 \pm 1.8$ & $3.6 \pm 2.3$ & -0.7242 \\
\hline P-to-Mg ratio & $0.9 \pm 0.3$ & $0.6 \pm 0.1$ & 2.4595 \\
\hline
\end{tabular}

${ }^{a}$ Instead of the $t$-value, the $W$-value from the Wilcoxon rank-sum test is displayed here

$\cdot 0.1 \geq p>0.05, * 0.05 \geq p>0.01, * * 0.01 \geq p>0.001, * * * p \leq 0.001$

$\mathrm{Mg}: \mathrm{Ca}$ ratio was higher in $\mathrm{AM}$ shoots and the $\mathrm{P}: \mathrm{Mg}$ ratio lower, indicating higher relative $\mathrm{Mg}$ allocation to shoots.

\section{$3.3 \mathrm{pH}$}

The statistical mixed effects model indicated that the treatment had no significant effect on the $\mathrm{pH}$ of the sand, whereas the effect of the compartment was significant (Table 3 ). However, there was a significant interaction effect between treatment and compartment. The lowest mean $\mathrm{pH}$ was found in the mycorrhizal compartments (6.54) of AM plants and the root compartment of the control plants (6.75), which would explain the occurrence of the interaction effect between compartment and treatment (Fig. 2). A negative correlation, between the $\mathrm{pH}$ in the root compartments and 
Table 2 Below-ground biomass data and carbon, nitrogen, phosphorus, calcium and magnesium contents of root biomass, as well as the respective elemental ratios $(n=5)$. Elemental ratios are molar ratios. Mean \pm SD. Data analysed via two-tailed unpaired $t$-test. Statistically significant values are shown in bold

\begin{tabular}{|c|c|c|c|}
\hline & Control & $\mathrm{AM}$ & $t$-Value \\
\hline $\begin{array}{l}\text { Root dry matter } \\
{\left[\mathrm{g} \mathrm{pot}^{-1}\right]}\end{array}$ & $12.0 \pm 4.1$ & $3.9 \pm 1.5$ & 4.1116** \\
\hline Root-to-shoot ratio & $1.8 \pm 0.6$ & $0.7 \pm 0.2$ & $3.8291 *$ \\
\hline $\begin{array}{l}\text { Total root C } \\
{\left[\mathrm{g} \mathrm{pot}^{-1}\right]}\end{array}$ & $1.4 \pm 0.3$ & $1.0 \pm 0.3$ & $2.9280 * *$ \\
\hline $\begin{array}{l}\text { Root C } \\
{\left[\mathrm{g} \mathrm{kg}^{-1}\right]}\end{array}$ & $120 \pm 32$ & $263 \pm 41$ & $-8.7177 * * *$ \\
\hline $\begin{array}{l}\text { Total root N } \\
{\left[\mathrm{g} \mathrm{pot}^{-1}\right]}\end{array}$ & $0.034 \pm 0.006$ & $0.035 \pm 0.01$ & -0.2562 \\
\hline $\begin{array}{l}\text { Root N } \\
{\left[\mathrm{g} \mathrm{kg}^{-1}\right]}\end{array}$ & $3.1 \pm 0.9$ & $9.2 \pm 1.7$ & $-10.1660 * * *$ \\
\hline C-to-N ratio & $46.4 \pm 2.6$ & $33.6 \pm 1.0$ & $10.1590 * * *$ \\
\hline $\begin{array}{l}\text { Total root P } \\
{\left[\mathrm{mg} \mathrm{pot}^{-1}\right]}\end{array}$ & $6.3 \pm 1.3$ & $3.5 \pm 1.3$ & $3.3644 * *$ \\
\hline $\begin{array}{l}\text { Root P } \\
{\left[\mathrm{mg} \mathrm{kg}^{-1}\right]}\end{array}$ & $5,577 \pm 1,708$ & $9,070 \pm 1,532$ & $-3.4036^{* *}$ \\
\hline $\mathrm{N}$-to-P ratio & $12.2 \pm 2.4$ & $22.6 \pm 4.0$ & $-5.0130 * *$ \\
\hline $\begin{array}{l}\text { Total root Ca } \\
{\left[\mathrm{mg} \mathrm{pot}^{-1}\right]}\end{array}$ & $5.8 \pm 1.1$ & $5.1 \pm 3.2$ & 0.4783 \\
\hline $\begin{array}{l}\text { Root Ca } \\
{\left[\mathrm{mg} \mathrm{kg}^{-1}\right]}\end{array}$ & $5,075 \pm 1,185$ & $8,417 \pm 1,097$ & $-2.7982 *$ \\
\hline $\begin{array}{l}\text { Total root Mg } \\
{\left[\mathrm{mg} \mathrm{pot}^{-1}\right]}\end{array}$ & $6.0 \pm 1.3$ & $3.2 \pm 1.1$ & $3.7579 * *$ \\
\hline $\begin{array}{l}\text { Root Mg } \\
{\left[\mathrm{mg} \mathrm{kg}^{-1}\right]}\end{array}$ & $5,301 \pm 1,185$ & $8,417 \pm 1,097$ & $-4.3159 * *$ \\
\hline Mg-to-Ca ratio & $1.7 \pm 0.3$ & $1.2 \pm 0.3$ & $2.7064 *$ \\
\hline P-to-Ca ratio & $1.4 \pm 0.3$ & $1.0 \pm 0.2$ & $2.3631 *$ \\
\hline P-to-Mg ratio & $0.8 \pm 0.1$ & $0.8 \pm 0.1$ & -0.6833 \\
\hline
\end{tabular}

$* 0.05 \geq p>0.01, * * 0.01 \geq p>0.001, * * * p \leq 0.001$

the plant $\mathrm{P}$ uptake, was found (Pearson's correlation coefficient $=-0.8435, p=0.0022$ ) (Supplementary material Fig. S2). Where the $\mathrm{pH}$ was lower, plants had a higher $\mathrm{P}$ content.

\subsection{Plant-available P}

Overall, there was more water-extractable $\mathrm{P}$ compared to CAL-extractable P detected in the sand (Table 4). The statistical model showed no significant effect of the treatment on the water-extractable P content (Table 3). Water- and CAL-extractability of $\mathrm{P}$ from struvite in the beginning of the experiment was $8.8 \mathrm{mg} \mathrm{kg}^{-1}$ and $17.1 \mathrm{mg} \mathrm{kg}^{-1}$, respectively. Water-extractability of struvite-P had greatly increased by the end of the 72-day experiment, whereas CAL-extractability did not increase much. P-extractability did not differ between bulk soil and mycorrhizal compartments, but only differed between bulk soil and root compartments (Table 4).
Table 3 Results from mixed effects models containing the factors 'Compartment', 'Treatment' and the interaction term 'Compartment $\mathrm{x}$ Treatment'. Statistically significant values are shown in bold

\begin{tabular}{|c|c|c|}
\hline & Factors and interactions & $\boldsymbol{F}$-value \\
\hline \multirow[t]{3}{*}{$\mathrm{pH}$} & Compartment & $9.6400 * *$ \\
\hline & Treatment & 0.4700 \\
\hline & Compartment $\mathrm{x}$ Treatment & $28.2100 * * *$ \\
\hline \multirow[t]{3}{*}{ Water-extractable P } & Compartment & $19.1400 * * *$ \\
\hline & Treatment & 4.9754 \\
\hline & Compartment $\mathrm{x}$ Treatment & $11.8673 * * *$ \\
\hline \multirow[t]{4}{*}{ CAL-extractable P } & Compartment $^{\mathrm{a}}$ & $5.8193 *$ \\
\hline & Treatment $^{\mathrm{a}}$ & 3.9131 . \\
\hline & Compartment $\mathrm{x}$ Treatment & 3.6010 \\
\hline & Compartment & $9.2662 * *$ \\
\hline \multirow[t]{2}{*}{$\mathrm{P}_{\mathrm{H} 2 \mathrm{O}}$-to- $\mathrm{P}_{\mathrm{CAL}}$ ratio } & Treatment & 0.8205 \\
\hline & Compartment $\mathrm{x}$ Treatment & $6.4912 * *$ \\
\hline
\end{tabular}

${ }^{a}$ Displayed are F-values derived from fixed effects model after model simplification by removal of the interaction term

$\cdot 0.1 \geq p>0.05, * 0.05 \geq p>0.01, * * 0.01 \geq p>0.001, * * * p \leq 0.001$

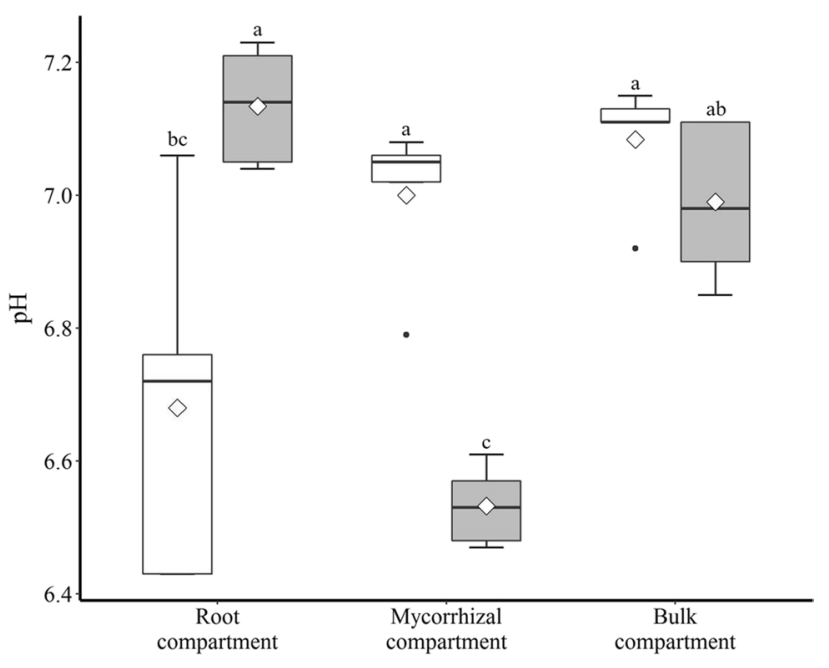

Fig. 2 Displaying the $\mathrm{pH}$ values of different compartments and treatments: control (white) and AM (grey). Mean is indicated by diamond. For root compartments and for mycorrhizal and bulk compartments $(n=5)$

It can be seen that a large part (24 to $38 \%$ ) of the amount originally added to each compartment $\left(100 \mathrm{mg} \mathrm{P} \mathrm{kg}^{-1}\right)$, was still present as water-extractable or CAL-extractable $\mathrm{P}$ at the time of harvest (Table 4). Phosphorus removal from the AM mycorrhizal compartments was not greater compared to the control mycorrhizal compartments. Phosphorus removal inside the control root compartments was substantially larger.

The fertiliser recovery efficiency, defined as the proportion of applied struvite-P recovered in plant biomass, was about $7 \%$ in the control treatment and about $3.5 \%$ in 
Table 4 Plant-available phosphorus concentration extracted with water $\left(\mathrm{P}_{\mathrm{H} 2 \mathrm{O}}\right)$ and calcium-acetate-lactate $\left(\mathrm{P}_{\mathrm{CAL}}\right)$ solution from each compartment of the boxes. Mean $\pm \mathrm{SD}$. $R$ root compartment, $M$ mycorrhizal compartment, $B$ bulk soil compartment $(n=5)$. Significant differences from the mixed effects model, considering both treatments and compartments simultaneously, are indicated by different letters across rows and columns. No significant difference was detected between treatments for $\mathrm{P}_{\mathrm{CAL}}$; therefore, mean values across both treatments are displayed

\begin{tabular}{|c|c|c|c|}
\hline & Compartment & Control & $\mathrm{AM}$ \\
\hline \multirow{3}{*}{$\begin{array}{l}\mathrm{P}_{\mathrm{H} 2 \mathrm{O}} \\
{\left[\mathrm{mg} \mathrm{P} \mathrm{kg}^{-1} \text { sand }\right]}\end{array}$} & $\mathrm{R}$ & $27.2 \pm 2.8 \mathrm{~b}$ & $38.2 \pm 4.5 \mathrm{a}$ \\
\hline & M & $42.9 \pm 6.3 a$ & $40.0 \pm 5.7 \mathrm{a}$ \\
\hline & B & $37.6 \pm 4.3 \mathrm{a}$ & $39.6 \pm 4.9 \mathrm{a}$ \\
\hline \multirow{3}{*}{$\begin{array}{l}\mathrm{P}_{\mathrm{CAL}} \\
{\left[\mathrm{mg} \mathrm{P} \mathrm{kg}^{-1} \text { sand] }\right.}\end{array}$} & $\mathrm{R}$ & \multicolumn{2}{|c|}{$18.2 \pm 3.0 \mathrm{~b}$} \\
\hline & $\mathrm{M}$ & \multicolumn{2}{|c|}{$20.0 \pm 2.0 \mathrm{ab}$} \\
\hline & $\mathrm{B}$ & \multicolumn{2}{|c|}{$21.3 \pm 2.6 \mathrm{a}$} \\
\hline \multirow[t]{3}{*}{$\mathrm{P}_{\mathrm{H} 2 \mathrm{O}^{-}}$to- $\mathrm{P}_{\mathrm{CAL}}$ ratio } & $\mathrm{R}$ & $1.1 \pm 0.2 b$ & $1.5 \pm 0.3 \mathrm{ab}$ \\
\hline & M & $1.8 \pm 0.4 \mathrm{a}$ & $1.6 \pm 0.2 \mathrm{ab}$ \\
\hline & $\mathrm{B}$ & $1.4 \pm 0.3 b$ & $1.5 \pm 0.2 \mathrm{ab}$ \\
\hline
\end{tabular}

Table 5 Distribution of applied phosphorus in plant and soil fractions from all compartments combined $(n=5)$. Mean \pm SD. Data analysed via two-tailed unpaired $t$-test. Statistically significant values are shown in bold

\begin{tabular}{|c|c|c|c|}
\hline & Control & $\mathrm{AM}$ & $t$-Value \\
\hline $\begin{array}{l}\text { Shoot P } \\
{[\% \text { of applied P] }}\end{array}$ & $6.1 \pm 1.1$ & $3.0 \pm 0.5$ & $5.0186 * * *$ \\
\hline $\begin{array}{l}\text { Root P } \\
{[\% \text { of applied } \mathrm{P}]}\end{array}$ & $0.76 \pm 0.1$ & $0.43 \pm 0.1$ & $3.3723 * *$ \\
\hline $\begin{array}{l}\mathrm{P}_{\mathrm{H} 2 \mathrm{O}} \\
{[\% \text { of applied } \mathrm{P}]}\end{array}$ & $34.4 \pm 2.2$ & $37.9 \pm 4.3$ & -1.4547 \\
\hline $\begin{array}{l}\mathrm{P}_{\mathrm{CAL}} \\
{[\% \text { of applied } \mathrm{P}]}\end{array}$ & $24.4 \pm 1.5$ & $24.8 \pm 1.8$ & -0.3862 \\
\hline
\end{tabular}

** $0.01 \geq p>0.001, * * * p \leq 0.001$

the AM treatment (Table 5). In contrast to this, 34 to $38 \%$ of total struvite-P applied per box was found as waterextractable $\mathrm{P}$ and 24 to $25 \%$ as CAL-extractable $\mathrm{P}$ in the sand-struvite mixture. The lowest percentage of water- and CAL-extractable $\mathrm{P}$ was recovered from the control root compartments, with 21 and 19\%, respectively (Table S1). A relatively higher percentage of water-extractable struvite-P was recovered from the mycorrhizal compartments of both treatments in comparison to the respective bulk soil compartments (Table S1). This was not the case for the CALextractable struvite-P, where recovery was highest in the bulk soil compartments relative to the mycorrhizal compartments (Table S1). Thus overall, a large part of applied struvite-P was not recovered in the control treatment and the AM treatment. Next to remaining non-extractable struvite-P, the unrecovered $\mathrm{P}$ could also be present in precipitated $\mathrm{P}$, such as Ca phosphate, in rhizodeposits not recovered and in mycorrhizal biomass in the case of the AM treatment.

\section{Discussion}

It is often reported that plants colonised by AM show a positive growth or yield response and improved $\mathrm{P}$ uptake (Delavaux et al. 2017). This is also often observed with $R$. irregularis as the mycorrhizal partner (Deepika and Kothamasi 2015; Garg and Pandey 2015; Tran et al. 2019), but a species-specific diversity of responses is possible, with $\mathrm{C}_{3}$ grasses benefiting less in comparison to $\mathrm{C}_{4}$ grasses (Tran et al. 2019). A positive yield response or improved $\mathrm{P}$ uptake was not evident in the present experiment. Plant $\mathrm{P}$ uptake of AM plants was lower compared to control plants. This is in contradiction to one other study, investigating the effect of mycorrhizae on struvite solubilisation, which found an increased $\mathrm{P}$ benefit to tomato plants fertilised with struvite (Di Tomassi et al. 2021). It is known that not all plant species respond positively to AM in terms of biomass development and P uptake (Hoeksema et al. 2010). The trade balance model of Johnson (2010) suggests that a range of interactions between mycorrhizae and their plant host are possible, from parasitic to mutualistic, depending on $\mathrm{C}, \mathrm{N}$ and $\mathrm{P}$ availabilities. Results of Nouri et al. (2014) show that under nutrient limiting conditions, for $P$ and $\mathrm{N}$, the symbiosis is beneficial. When nutrient supply was not limited, AM colonisation of roots was very low. When either $\mathrm{N}$ or $\mathrm{P}$ were in short supply, colonisation levels increased, but when plants were given $\mathrm{P}$ only and no $\mathrm{N}$ or any other nutrients, the high root colonisation level did not induce a positive growth response and also decreased $\mathrm{P}$ uptake. This supports the commensalism scenario of Johnson (2010) where high $\mathrm{P}$ availability reduces the $\mathrm{P}$ trade benefit but $\mathrm{N}$-limitation keeps $\mathrm{C}$-consumption by $\mathrm{AM}$ in a relatively low range where it does not impact the plant negatively. Therefore, the results of Nouri et al. (2014) and the trade balance model by Johnson (2010) could hold a possible explanation for the lower $\mathrm{P}$ nutrition and lack of growth response in our experiment. In the beginning of the experiment, the plants were supplied with all essential nutrients, but mid-way through the experiment, the nutrient solution was replaced with distilled water only. The main nutrients remaining available to the plants were $\mathrm{P}, \mathrm{N}$ and $\mathrm{Mg}$ from struvite mixed into the sand at the beginning of the experiment, but symbiosis did not induce a positive $\mathrm{P}$ nutrition response for the AM plants. This was possibly due to $\mathrm{N}$-limitation relative to $\mathrm{P}$ availability induced by the narrow $\mathrm{N}: \mathrm{P}$ ratio of struvite, which is one. In addition, the plant $\mathrm{N}$-concentration in the control treatment also indicate $\mathrm{N}$-limitation versus a high consumption of $\mathrm{P}$ (Huber et al. 2012). In future studies, nutrient supply by Hoagland solution should be continued for a longer time period. Furthermore, the high concentration of struvite-P applied in this experiment may be a reason for the lack of 
a beneficial effect on the AM plants in terms of P uptake. It is known that the beneficial effect of AM is most predominant under low P supply (Johnson 2010; Smith and Read 2008b). Nevertheless, whether the AM colonisation was beneficial in the early stages of the experiment, when $\mathrm{P}$ release from struvite may have been slow, is not known and should be investigated in future studies.

The AM treatment, contrary to expectation, induced neither more $\mathrm{P}$ removal from the root compartment nor from the mycorrhizal compartments compared to the controls and bulk soil compartments as indicated by extractable P. On the contrary, the roots of the control plants depleted the extractable $\mathrm{P}$ pools more than the AM roots and hyphae. This result fits well with the observed lower P concentration in the AM plants. Possible causes, discussed by Nazeri et al. (2014) for the lack of $\mathrm{P}$ depletion in the rhizosphere, may be a reduced uptake by mycorrhizal roots due to downregulation of direct root $\mathrm{P}$ uptake, increased efflux of excess $\mathrm{P}$ from plant roots well-supplied with $\mathrm{P}$ or the release of $\mathrm{P}$ from mycorrhizal hyphae. It is unclear which of these possible causes may have contributed to the results observed in this study. Luxury consumption of $\mathrm{P}$ by plants in this study may have been prevented in mycorrhizal plants contrary to control plants, similarly to observations of Nazeri et al. (2014). In their study, it has also been found that shoot allocation of $\mathrm{P}$ in mycorrhizal plants was significantly lower, in comparison to control plants, albeit shortly after application of a P pulse in their case. Therefore, efflux of excess $\mathrm{P}$ from roots or hyphae or a reduced uptake in the first place may all be possible explanations of the lower P uptake and higher P recovery from rhizosphere and hyphosphere of mycorrhizal plants in comparison to control plants, observed in the present study.

The hyphal network of AM can substitute for the function of a fine extensive root system developed by plants, when their investment of $\mathrm{C}$ into AM symbiosis becomes beneficial. In our experiment, the AM plants invested less into root growth, which is commonly observed (Veresoglou et al. 2012). However, the hyphal network delivered less $P$ to the plant shoot compared to the extensive root system developed by the control plants, indicating no benefit from the $\mathrm{C}$ investment into the AM symbiosis in terms of $\mathrm{P}$ uptake. It was recently suggested by Verlinden et al. (2018) that the $\mathrm{C}$ economy of $\mathrm{P}$ acquisition was still beneficial in the case of highly mycotrophic maize plants, even under adequately fertilised conditions. However, as we did not investigate the $\mathrm{C}$ transfer into the mycorrhizosphere, we cannot assess the $\mathrm{C}$ economy of the AM plants in terms of $\mathrm{P}$ acquisition. This should be the focus of future investigations using isotopically enriched struvite and $\mathrm{C}$ labelled plants.

Contrary to expectations, water-extractable $\mathrm{P}$ concentrations were consistently higher than those extracted by CAL (Table 4). We interpret this anomaly as being due to a combination of factors. The air-drying of samples has been observed to increase solubility of $\mathrm{P}$ in water (Bartlett and James 1980). Water can potentially extract more $P$ than salt solutions containing $\mathrm{Ca}$ due to precipitation of $\mathrm{Ca}$ phosphates (Self-Davis et al. 2000). While the acidic pH of CAL should exclude this, it is possible that the activated carbon used in the CAL protocol (Schüller 1969) re-adsorbed a portion of the displaced phosphate. Furthermore, we observed abnormally high blank values in the CAL analyses (data not shown) which led to a negative bias being superimposed on the calculated concentrations. Water- and CAL-extractability of $\mathrm{P}$ did not indicate an influence of the treatment on the solubility of struvite. As shown in the results, a large part of the struvite used in our experiment was water- or CAL-extractable after 72 days, which made it easily available to the plants as indicated by the absence of deficiency symptoms. This is in line with Vogel et al. (2015), where available P pools in soil increased after struvite application and struvite was considered to be an effective P source for several different plants. Recently, the struvite used in the present experiment was shown to be a very good source of $\mathrm{P}$ and $\mathrm{Mg}$ to ryegrass (Watson et al. 2019). However, in our experiment, only a small proportion of applied $\mathrm{P}$ was found in the plant biomass at the end of our experiment, which may have been due to reduced plant growth as caused by other limiting nutrients or by satisfied $\mathrm{P}$ demand of the growing plants. It should not be overlooked that plants were harvested at the vegetative stage, and further $\mathrm{P}$ uptake would have occurred at a later growth stage contributing to a more efficient struvite-P use. Moreover, struvite-P in the bulk soil compartment was not accessible for plant roots or mycorrhizae and most likely also did not diffuse towards the mycorrhizal and root compartments, thus leaving it an unused fraction of applied fertilizer, which accounted for approximately $57 \%$ of applied P.

Acidification in some of the compartments did not impact the solubility of struvite as there were mostly no differences in extractable $\mathrm{P}$ between compartments. The negative correlation between the $\mathrm{pH}$ inside the root compartments and the plant $\mathrm{P}$ content suggests that plant $\mathrm{P}$ uptake was higher at a lower $\mathrm{pH}$. This confers with results from Li et al. (1991), where ammonium-fed plants contributed to rhizosphere acidification which supported $\mathrm{P}$ uptake by mobilisation of Ca phosphates. Alternatively, it has been shown elsewhere that mycorrhizal colonisation reduced carboxylic acids in the rhizosphere and thereby contributed to an increased $\mathrm{pH}$ in the rhizosphere of mycorrhizal roots (Nazeri et al. 2014). The factor contributing to the observed $\mathrm{pH}$ decrease inside some of the compartments in this experiment is not clear. Although organic acid exudation by mycorrhizae has been hypothesised, evidence supporting this hypothesis has not been confirmed yet and further investigations are required (Di Tomassi et al. 2021; Tawaraya et al. 2006). A more indirect influence on the acidification of the mycorrhizal compartment by AM releasing hydrogen ions seems more likely 
(Bolan 1991). It is known that the form of nitrogen supplied $\left(\mathrm{NH}_{4}{ }^{+}\right.$or $\left.\mathrm{NO}_{3}{ }^{-}\right)$to the plant influences the $\mathrm{pH}$ (White 2012). Ammonium-fed plants and mycorrhizae, as observed by Li et al. (1991), contribute to acidification by releasing hydrogen ions into the soil. As the plants in this experiment received both nitrate and ammonium, $\mathrm{pH}$ changes are not clearly attributable to the sole uptake of one form of nitrogen. However, struvite contains ammonium, which might have been taken up by roots in the root compartment of the control treatment and by mycorrhizae in the mycorrhizal compartment in the AM treatment, resulting in proton release and thus a $\mathrm{pH}$ decrease, as observed in the control root compartments and mycorrhizal compartments of treated plants. Preferential uptake of $\mathrm{NH}_{4}{ }^{+}$by mycorrhizae has been suggested (Jin et al. 2012). Acidification of the mycorrhizal compartment by $\mathrm{AM}$, possibly due to $\mathrm{NH}_{4}{ }^{+}$uptake, fits well with the similar $\mathrm{N}$-uptake by both control and treated plants, despite the lower root biomass of AM plants. Acidification of $\mathrm{NH}_{4}{ }^{+}$fed plants, mycorrhizal or not, is often observed (Bago and Azcón-Aguilar 1997; Li et al. 1991; Villegas et al. 1996), but the connection between acidification, due to $\mathrm{NH}_{4}{ }^{+}$, and an increased P-depletion is not always observed as clearly (Ortas et al. 1996; Villegas et al. 1996) as it has been by Li et al. (1991). This is also the case for the current study where an increased acidification in connection with an increased P-depletion was only observed in the control root compartment, whereas acidification in mycorrhizal compartments of treated plants did not lead to an increased P-depletion. Interestingly, even though they did not increase the $\mathrm{P}$ concentration and the $\mathrm{P}$ content of AM plants, mycorrhizae increased relative shoot $\mathrm{Mg}$ allocation as indicated by the increased $\mathrm{Mg}: \mathrm{Ca}$ and the decreased $\mathrm{P}: \mathrm{Mg}$ ratios in the $\mathrm{AM}$ shoots. One reason might be enhanced $\mathrm{Mg}$ uptake from struvite, even though the $\mathrm{P}: \mathrm{Mg}$ ratio in the control treatment more strongly resembles the $\mathrm{P}: \mathrm{Mg}$ ratio of struvite. However, this was not observed in the roots, where control plants had a higher $\mathrm{Mg}$ : $\mathrm{Ca}$ ratio and the $\mathrm{P}: \mathrm{Mg}$ ratio did not differ. The role of struvite as magnesium source requires more investigation as mentioned earlier (Watson et al. 2019).

\section{Conclusions}

The results of our experiment show that mycorrhizal inoculation may not necessarily result in increased plant growth and does not allow better P uptake from struvite. Here, AM colonisation of rye plants by $R$. irregularis had a negative effect on plant root biomass and reduced total $\mathrm{P}$ content and $\mathrm{P}$ concentration of above-ground biomass. Further plant-AM species combinations should be tested. The altered biomass partitioning with reduced root biomass in the AM treated plants may reflect a stronger plant $\mathrm{C}$ allocation to mycorrhizae. Even though root biomass was reduced in the AM plants, nutrient concentrations were higher as compared to control plants, which may have allowed AM plants to remobilise and reallocate nutrients to the shoot at later growth stages or when availability in the soil was low. Reduced root biomass and thus lower nutrient uptake by roots lowered acidification in the rhizosphere, whereas the hyphosphere lowered the $\mathrm{pH}$ in the compartment not accessible to roots.

Supplementary Information The online version contains supplementary material available at https://doi.org/10.1007/s42729-021-00619-5.

Acknowledgements We acknowledge the kind help of Franz Kuhnigk, Rebecca Grossmann, Lara Kohl, Lars Caspersen, Elisabeth Sailer, Jakob Vögerl, Julia Gorris, Lia Moreno Codinachs and Timo Preißing.

Author Contribution Conceptualisation: Sanja Schwalb, Conor Watson, Florian Wichern.

Methodology: Sanja Schwalb, Michael Hemkemeyer, Conor Watson, Florian Wichern.

Formal analysis and investigation: Sanja Schwalb, Michael Hemkemeyer, Conor Watson, Florian Wichern.

Writing - original draft: Sanja Schwalb.

Writing-review and editing: Michael Hemkemeyer, Conor Watson, Florian Wichern.

Supervision: Conor Watson, Florian Wichern.

Funding Open Access funding enabled and organized by Projekt DEAL.

Data Availability Data and materials can be made available upon request.

Code Availability Not applicable.

\section{Declarations}

Conflict of interest The authors declare no competing interests.

Open Access This article is licensed under a Creative Commons Attribution 4.0 International License, which permits use, sharing, adaptation, distribution and reproduction in any medium or format, as long as you give appropriate credit to the original author(s) and the source, provide a link to the Creative Commons licence, and indicate if changes were made. The images or other third party material in this article are included in the article's Creative Commons licence, unless indicated otherwise in a credit line to the material. If material is not included in the article's Creative Commons licence and your intended use is not permitted by statutory regulation or exceeds the permitted use, you will need to obtain permission directly from the copyright holder. To view a copy of this licence, visit http://creativecommons.org/licenses/by/4.0/.

\section{References}

Bago B, Azcón-Aguilar C (1997) Changes in the rhizospheric pH induced by arbuscular mycorrhiza formation in onion (Allium cepa L.). J Plant Nutr Soil Sci 160:333-339. https://doi.org/10. 1002/jpln.19971600231 
Bartlett R, James B (1980) Studying dried, stored soil samples — some pitfalls. Soil Sci Soc Am J 44:721-724. https://doi.org/10.2136/ sssaj1980.03615995004400040011x

Bolan NS (1991) A critical review on the role of mycorrhizal fungi in the uptake of phosphorus by plants. Plant Soil 134:189-207. https://doi.org/10.1007/BF00012037

Brundrett MC, Abbott LK (2004) Arbuscular mycorrhizas in plant communities:151-193. https://doi.org/10.1007/0-306-48099-9_6

Deepika S, Kothamasi D (2015) Soil moisture-a regulator of arbuscular mycorrhizal fungal community assembly and symbiotic phosphorus uptake. Mycorrhiza 25:67-75. https://doi.org/10.1007/ s00572-014-0596-1

Delavaux CS, Smith-Ramesh LM, Kuebbing SE (2017) Beyond nutrients: a meta-analysis of the diverse effects of arbuscular mycorrhizal fungi on plants and soils. Ecology 98:2111-2119. https:// doi.org/10.1002/ecy.1892

Di Tomassi I, Chatterjee N, Barrios-Masias FH, Zhou Q, Gu C, Margenot AJ (2021) Arbuscular mycorrhizae increase biomass and nutrient uptake of tomato fertilized with struvite compared to monoammonium phosphate. Plant Soil 464:321-333. https:// doi.org/10.1007/s11104-021-04957-2

Garg N, Pandey R (2015) Effectiveness of native and exotic arbuscular mycorrhizal fungi on nutrient uptake and ion homeostasis in salt-stressed Cajanus cajan L. (Millsp.) genotypes. Mycorrhiza 25:165-180. https://doi.org/10.1007/s00572-014-0600-9

Graves S, Piepho H, Selzer L, Dorai-Raj S (2015) multcompView: visualizations of paired comparisons. R package version 0.1-7. https://CRAN.R-project.org/package $=$ multcompView

Hayman DS, Mosse B (1972) Plant growth responses to vesiculararbuscular mycorrhiza - Increased uptake of labile P from soil. New Phytol 71:41-47

Hoeksema JD, Chaudhary VB, Gehring CA, Johnson NC, Karst J, Koide RT, Pringle A, Zabinski C, Bever JD, Moore JC, Wilson GWT, Klironomos JN, Umbanhowar J (2010) A meta-analysis of context-dependency in plant response to inoculation with mycorrhizal fungi. Ecol Lett 13:394-407. https://doi.org/10. 1111/j.1461-0248.2009.01430.x

Huber D, Römheld V, Weinmann M (2012) Chapter 10 - relationship between nutrition, plant diseases and pests. In: Marschner P (ed) Marschner's Mineral Nutrition of Higher Plants, 3rd edn. Academic Press, San Diego, pp 283-298

Jin H, Liu J, Liu J, Huang X (2012) Forms of nitrogen uptake, translocation, and transfer via arbuscular mycorrhizal fungi: a review. Sci China Life Sci 55:474-482. https://doi.org/10.1007/ s11427-012-4330-y

Johnson NC (2010) Resource stoichiometry elucidates the structure and function of arbuscular mycorrhizas across scales. New Phytol 185:631-647. https://doi.org/10.1111/j.1469-8137.2009. 03110.x

Lenth R (2019) emmeans: Estimated marginal means, aka leastsquares means. https://CRAN.R-project.org/package=emmeans

Li X-L, George E, Marschner H (1991) Phosphorus depletion and $\mathrm{pH}$ decrease at the root-soil and hyphae-soil interfaces of VA mycorrhizal white clover fertilized with ammonium. New Phytol 119:397-404. https://doi.org/10.1111/j.1469-8137.1991. tb00039.x

Meier U (2018) Entwicklungsstadien mono- und dikotyler Pflanzen: BBCH Monografie. Open Agrar Repositorium, Quedlinburg

Murphy J, Riley JP (1962) A modified single solution method for the determination of phosphate in natural waters. Anal Chim Acta 27:31-36. https://doi.org/10.1016/S0003-2670(00)88444-5

Muys M, Phukan R, Brader G, Samad A, Moretti M, Haiden B, Pluchon S, Roest K, Vlaeminck SE, Spiller M (2021) A systematic comparison of commercially produced struvite: quantities, qualities and soil-maize phosphorus availability. Sci Total Environ 756:143726. https://doi.org/10.1016/j.scitotenv.2020.143726
Nazeri NK, Lambers H, Tibbett M, Ryan MH (2014) Moderating mycorrhizas: arbuscular mycorrhizas modify rhizosphere chemistry and maintain plant phosphorus status within narrow boundaries. Plant Cell Environ 37:911-921. https://doi.org/10. $1111 /$ pce. 12207

Nouri E, Breuillin-Sessoms F, Feller U, Reinhardt D (2014) Phosphorus and nitrogen regulate arbuscular mycorrhizal symbiosis in Petunia hybrida. PLoS ONE 9:e90841. https://doi.org/10. 1371/journal.pone.0090841

Ortas I, Harris PJ, Rowell DL (1996) Enhanced uptake of phosphorus by mycorrhizal sorghum plants as influenced by forms of nitrogen. Plant Soil 184:255-264. https://doi.org/10.1007/ BF00010454

Pinheiro J, Bates D, CDebRoy S, Sarkar D, Team RC (2017) nmle: linear and nonlinear mixed effects models. https://CRAN.Rproject.org/package $=$ nlme

R Core Team (2017) R: A language and environment for statistical computing. Foundation for Statistical Computing, Vienna, Austria. https://www.R-project.org/

Schoumans OF, Bouraoui F, Kabbe C, Oenema O, van Dijk KC (2015) Phosphorus management in Europe in a changing world. Ambio 44(Suppl 2):S180-S192. https://doi.org/10.1007/ s13280-014-0613-9

Schüller H (1969) Die CAL-Methode, eine neue Methode zur Bestimmung des pflanzenverfügbaren Phosphates in Böden. Zeitschrift für Pflanzenernährung und Bodenkunde 123:48-63. https://doi.org/10.1002/jpln.19691230106

Self-Davis ML, Moore PA, Joern BC (2000) Determination of waterand/or dilute salt-extractable phosphorus. Methods of phosphorus analysis for soils, sediments, residuals, and waters, vol 396. Southern Coop. Ser. Bull

Smith SE, Read D (2008) 4 - Growth and carbon economy of arbuscular mycorrhizal symbionts. In: Smith SE, Read D (eds) Mycorrhizal Symbiosis, 3rd edn. Academic Press, London, pp 117-144

Smith SE, Read D (2008b) Mineral nutrition, toxic element accumulation and water relations of arbuscular mycorrhizal plants. In: Mycorrhizal symbiosis, 3rd edn. Academic Press, Amsterdam, Boston, 145-VI

Tarayre C, de Clercq L, Charlier R, Michels E, Meers E, CamargoValero M, Delvigne F (2016) New perspectives for the design of sustainable bioprocesses for phosphorus recovery from waste. Biores Technol 206:264-274

Tawaraya K, Naito M, Wagatsuma T (2006) Solubilization of insoluble inorganic phosphate by hyphal exudates of arbuscular mycorrhizal fungi. J Plant Nutr 29:657-665. https://doi.org/10.1080/ 01904160600564428

Tran BTT, Watts-Williams SJ, Cavagnaro TR (2019) Impact of an arbuscular mycorrhizal fungus on the growth and nutrition of fifteen crop and pasture plant species. Funct Plant Biol 46:732742. https://doi.org/10.1071/FP18327

Uysal A, Kuru B (2013) Examination of nutrient removal from anaerobic effluent of the dairy processing industry by struvite precipitation using the response surface methodology. Fresenius Environ Bull 22:1380-1387

van der Wiel BZ, Weijma J, van Middelaar CE, Kleinke M, Buisman CJN, Wichern F (2020) Restoring nutrient circularity: a review of nutrient stock and flow analyses of local agro-food-waste systems. Resour Conserv Recycl 160:104901. https://doi.org/ 10.1016/j.resconrec.2020.104901

Veresoglou SD, Chen B, Rillig MC (2012) Arbuscular mycorrhiza and soil nitrogen cycling. Soil Biol Biochem 46:53-62

Verlinden MS, Ven A, Verbruggen E, Janssens IA, Wallander H, Vicca S (2018) Favorable effect of mycorrhizae on biomass production efficiency exceeds their carbon cost in a fertilization 
experiment. Ecology 99:2525-2534. https://doi.org/10.1002/ ecy. 2502

Villegas J, Williams RD, Nantais L, Archambault J, Fortin JA (1996) Effects of $\mathrm{N}$ source on $\mathrm{pH}$ and nutrient exchange of extramatrical mycelium in a mycorrhizal Ri T-DNA transformed root system. Mycorrhiza 6:247-251. https://doi.org/10.1007/s0057 20050132

Vogel T, Nelles M, Eichler-Löbermann B (2015) Phosphorus application with recycled products from municipal waste water to different crop species. Ecol Eng 83:466-475. https://doi.org/ 10.1016/j.ecoleng.2015.06.044

Watson C, Clemens J, Wichern F (2019) Plant availability of magnesium and phosphorus from struvite with concurrent nitrification inhibitor application. Soil Use Manage 35:675-682. https://doi. org/10.1111/sum.12527
Watson C, Clemens J, Wichern F (2020) Hazenite: a new secondary phosphorus, potassium and magnesium fertiliser. Plant Soil Environ 66:1-6

White PJ (2012) Ion uptake mechanisms of individual cells and roots: short-distance transport, in Marschner, P.: Marschner's Mineral Nutrition of Higher Plants (Third Edition). Academic Press, San Diego, pp. 7-47.

Wrigley C, Bushuk W (2017) Chapter 7 - Rye: grain-quality characteristics and management of quality requirements. In: Wrigley C, Batey I, Miskelly D (eds) Cereal Grains (Second Edition): Woodhead Publishing Series in Food Science. Woodhead Publishing, Technology and Nutrition, pp 153-178

Publisher's Note Springer Nature remains neutral with regard to jurisdictional claims in published maps and institutional affiliations. 